\title{
Synthesis of $\beta$-Substituted Tryptamines by Regioselective Ring Opening of Aziridines
}

\author{
Jesse Kidd, Kristen Maiden, and Jeremy B. Morgan* \\ Department of Chemistry and Biochemistry, University of North Carolina Wilmington, Dobo Hall, Wilmington, \\ North Carolina 28403, United States \\ Corresponding author. Email address: morganj@uncw.edu
}

\begin{abstract}
Functionalized tryptamines are targets of interest for development as small molecule therapeutics. The ring opening of aziridines with indoles is a powerful method for tryptamine synthesis if site selectivity can be controlled. 4-Nitrobenzyl carbamate (PNZ)-protected aziridines undergo regioselective ring opening to produce $\beta$-substituted tryptamines for a series of indoles. The PNZ-protected tryptamines can be further manipulated by PNZ removal under mild conditions.
\end{abstract}

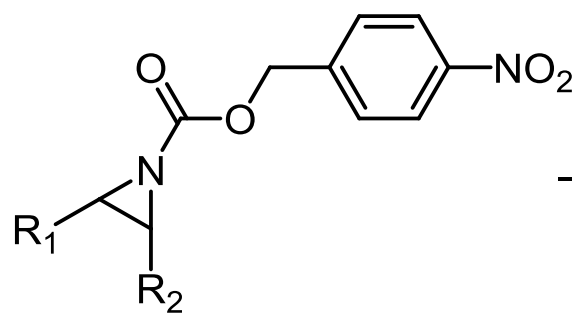

1 equiv $\mathrm{BF}_{3} \cdot \mathrm{OEt}_{2}$
$\stackrel{3 \text { equiv indole }}{\longrightarrow \mathrm{CH}_{2} \mathrm{Cl}_{2},-78{ }^{\circ} \mathrm{C}, 2 \mathrm{~h}}$

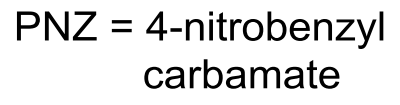<smiles>[R]CC([R2])c1cn([R])c2ccccc12</smiles>

12 examples yields up to $90 \%$ 
The demand for nitrogen-containing small molecules facilitates the search for new pathways to construct chiral amine building blocks. ${ }^{1}$ The ring opening of aziridines is a wellestablished method for incorporating nitrogen into organic molecules. ${ }^{2-4}$ Despite significant history in the development of aziridine opening, new advances are continuing to provide unique bond constructions and product selectivities. ${ }^{5-9}$ The inherent ring strain in aziridines is sufficient to initiate reactivity, but the nitrogen atom is often modified with an electron-withdrawing (protecting) group for increased activation. ${ }^{10}$ The resulting product retains this moiety as a nitrogen protecting group which must be removed prior to nitrogen functionalization. Synthetic design must account for the aziridine activation group to ensure its removal is compatible with ancillary functional groups in the final product.

Sulfonamides stand out as the most commonly utilized aziridine protecting groups for ring opening reactions. ${ }^{5,7,10}$ A majority of these methodologies incorporate the $p$ toluenesulfonamide (Ts) substrates, which are easy to generate from alkenes. ${ }^{11-13}$ However, the subsequent Ts deprotections can be challenging, and alternative sulfonamide-protected aziridines have been developed. ${ }^{14-17}$ Carbamates, such as benzyl (Cbz) and tert-butyl (Boc), can be removed under very mild conditions, but are less common as aziridine protecting groups since rearrangement byproducts are possible. ${ }^{18-21}$ The 4-nitrobenzyl carbamate (PNZ) had been sparingly used as an aziridine activating group until recently. ${ }^{22-31}$ The PNZ group is more activating than $\mathrm{Cbz}$ and more resistant to cleavage under acidic conditions.

Our group has been interested in the development of novel aziridine ring opening reactions, particularly for $N$-acylaziridines. ${ }^{32,33}$ The addition of indoles to aziridines produces tryptamine derivatives, which are known to possess extensive biological activity. ${ }^{34,35}$ An initial report of indoles adding to aziridinium ions ${ }^{36}$ was followed by methods for opening carbamateprotected aziridines. ${ }^{37,38}$ Extensive effort has been made to control the final tryptamine structure in high yield, ${ }^{21,39-41}$ where unsymmetrical aziridines, such as $\mathbf{1}$, can open at either backbone carbon (Scheme 1). For carbamate-protected aziridines with a $\mathrm{C} 2$ ester substituent $\left(\mathrm{R}_{1}\right)$, addition of indole to the least hindered carbon produces the $\alpha$-substituted tryptamine (2). Yields of $\mathbf{2}$ have steadily improved as new Lewis acid catalysts are developed and side reactions are minimized. ${ }^{21}$ The synthesis of a $\beta$-substituted tryptamine (3) from a mono-substituted aziridine has only been reported in low yields for carbamate-protected aziridines; ${ }^{21,42}$ however, limited examples with 
alternative nitrogen protecting groups are known. ${ }^{33,43}$ This report details our discovery that PNZprotected, alkyl substituted aziridines (4) undergo selective ring opening by $\mathrm{C} 2$ attack with indoles to produce $\beta$-substituted tryptamines (5) ${ }^{7,44,45}$ The tryptamine products can be readily functionalized at nitrogen after PNZ removal under mild conditions.
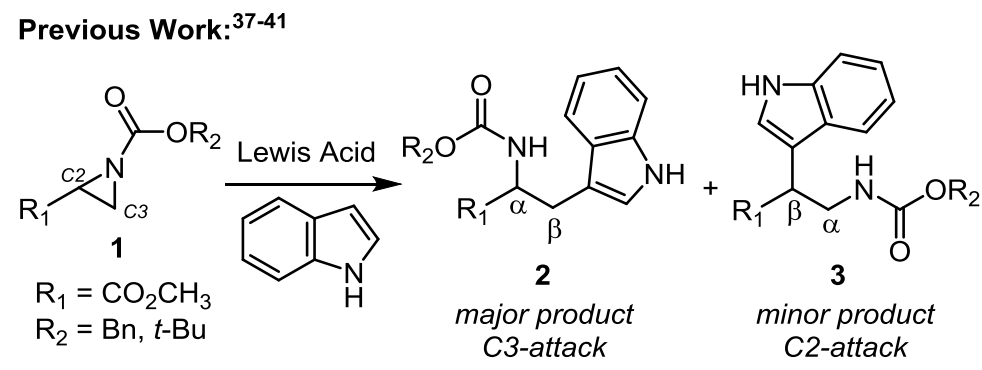

This Work:
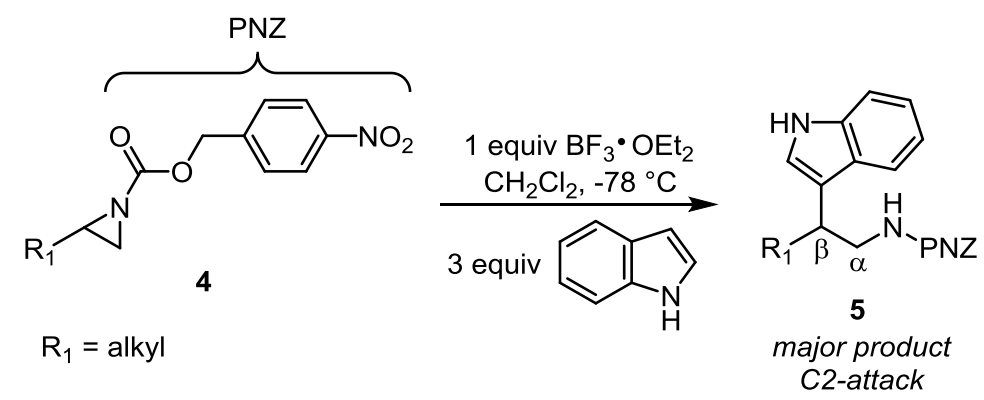

Scheme 1: Synthesis of Tryptamines by Indole Addition to Aziridines

Aziridine 6 was synthesized in racemic and enantiopure form and subjected to ring opening in the presence of 1-methylindole. The choice of $\mathrm{BF}_{3}$ as the Lewis acid promoter was directed by previous reports ${ }^{25-27,30,43}$ and unpublished data from our laboratory. The reaction conditions were remarkably mild with complete consumption of 6 in 1 hour at $-78^{\circ} \mathrm{C}$. The PNZprotected tryptamine (7) was isolated in $71 \%$ yield as a single enantiomer as confirmed by HPLC. ${ }^{46}$ Excess indole was employed, based on previous data, to maximize tryptamine yield. ${ }^{33}$

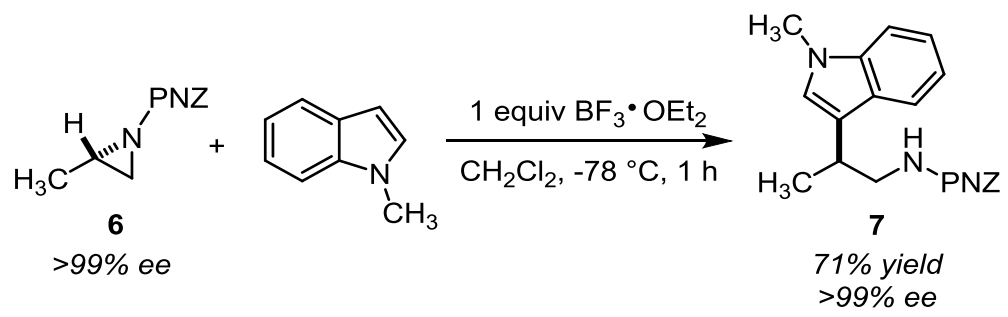

Scheme 2: Regioselective, Enantiospecific Ring Opening of Aziridine 6 
Optimized conditions for the $\mathrm{BF}_{3}$-promoted tryptamine synthesis were applied for a series of functionalized indoles (Table 1). The racemic aziridine 6 and a meso disubstituted PNZaziridine (8) were chosen for the investigation. Reactions were performed in duplicate on a 1 mmol scale to generate sufficient tryptamine for further functionalization. The yield for ring opening of rac-6 ranged from good to excellent with a variety of indole substitution patterns (entries 1-7). Tryptamines were produced in high regioselectivity favoring attack at the more substituted aziridine carbon. The 2, 5, and 6 positions of a $1 \mathrm{H}$-indole were well-tolerated with functional groups including an ether (entry 4) and halogens (entries 5-6). Slightly lower yields were observed for aziridine 8, compared to rac-6, with similar indoles (entries 8-12). The reactions with 2-methylindole (entries 2 and 9) produced the highest yields, indicating unidentified byproducts from attack at the indole $\mathrm{C} 2$ may be reducing product yield in the remaining examples.

Table 1: Substrate Scope for the Synthesis of $\beta$-Substituted Aziridines ${ }^{\mathrm{a}}$
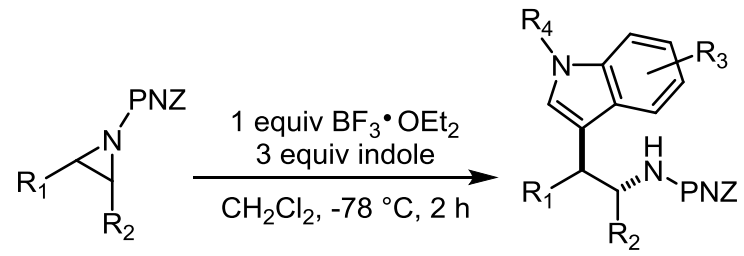

rac-6 or 8

\begin{tabular}{clccccc}
\hline entry & \multicolumn{1}{c}{$\mathrm{R}_{1}$} & $\mathrm{R}_{2}$ & $\mathrm{R}_{3}$ & $\mathrm{R}_{4}$ & product & yield (\%) $)^{\mathrm{b}, \mathrm{c}}$ \\
\hline 1 & $\mathrm{CH}_{3}$ & $\mathrm{H}$ & $\mathrm{H}$ & $\mathrm{H}$ & 9 & 60 \\
2 & $\mathrm{CH}_{3}$ & $\mathrm{H}$ & $2-\mathrm{CH}_{3}$ & $\mathrm{H}$ & 10 & $90^{\mathrm{d}}$ \\
3 & $\mathrm{CH}_{3}$ & $\mathrm{H}$ & $5-\mathrm{CH}_{3}$ & $\mathrm{H}$ & 11 & 62 \\
4 & $\mathrm{CH}_{3}$ & $\mathrm{H}$ & $5-\mathrm{OCH}_{3}$ & $\mathrm{H}$ & 12 & 75 \\
5 & $\mathrm{CH}_{3}$ & $\mathrm{H}$ & $5-\mathrm{Cl}$ & $\mathrm{H}$ & 13 & 63 \\
6 & $\mathrm{CH}_{3}$ & $\mathrm{H}$ & $6-\mathrm{F}$ & $\mathrm{H}$ & 14 & 57 \\
7 & $\mathrm{CH}_{3}$ & $\mathrm{H}$ & $\mathrm{H}$ & $\mathrm{CH}$ & rac-7 & 68 \\
8 & $-\mathrm{CH}_{2} \mathrm{CH}_{2} \mathrm{CH}_{2} \mathrm{CH}_{2}$ & $\mathrm{H}$ & $\mathrm{H}$ & 15 & 60 \\
9 & $-\mathrm{CH}_{2} \mathrm{CH}_{2} \mathrm{CH}_{2} \mathrm{CH}_{2}$ & $2-\mathrm{CH}_{3}$ & $\mathrm{H}$ & 16 & 76 \\
10 & $-\mathrm{CH}_{2} \mathrm{CH}_{2} \mathrm{CH}_{2} \mathrm{CH}_{2-}^{-}$ & $5-\mathrm{CH}_{3}$ & $\mathrm{H}$ & 17 & 56 \\
11 & $-\mathrm{CH}_{2} \mathrm{CH}_{2} \mathrm{CH}_{2} \mathrm{CH}_{2}^{-}$ & $5-\mathrm{OCH}_{3}$ & $\mathrm{H}$ & 18 & 62 \\
12 & $-\mathrm{CH}_{2} \mathrm{CH}_{2} \mathrm{CH}_{2} \mathrm{CH}_{2-}^{-}$ & $\mathrm{H}$ & $\mathrm{CH}_{3}$ & 19 & 48 \\
\hline
\end{tabular}

a) Reactions were performed with aziridine rac- 6 or $8(1 \mathrm{mmol})$, indole ( $3 \mathrm{mmol})$, and $\mathrm{BF}_{3} \cdot \mathrm{OEt}_{2}(1 \mathrm{mmol})$ in $\mathrm{CH}_{2} \mathrm{Cl}_{2}(0.17 \mathrm{M})$ for 2 hours at -78 ${ }^{\circ} \mathrm{C}$. b) Isolated yield from an average of 2 runs. $\mathrm{C}$ ) Product regioisomer ratio was $>10: 1$ based on ${ }^{1} \mathrm{H}$ NMR of entries 1 and 3-7. Entries 8-12 were formed as a racemic mixture. d) Regioisomer ratio of $7: 1$. 
We envisioned access to PNZ-protected, $\beta$-substituted tryptamines would provide a single intermediate for the synthesis of biologically relevant tryptamine derivatives. To this end, the PNZ group of 9 was readily removed under standard hydrogenation conditions. Tryptamine 20 was formed as a mixture with toluidine from PNZ reduction in quantitative yield. With this byproduct in mind, we employed literature methods to selectively functionalize the alkyl nitrogen of 20. Dimethylation ${ }^{47}(\mathbf{2 1})$ and benzylation ${ }^{48}(\mathbf{2 2})$ were accomplished by reductive amination in moderate yield. Site selective acylation led the melatonin-like tryptamine $\mathbf{2 3}$ in modest yield. ${ }^{49}$ Studies are underway to functionalize each PNZ-tryptamine in Table 1 to generate a library of molecules for biological activity screening.

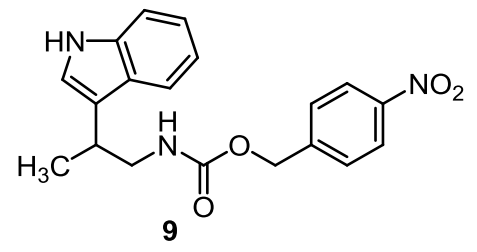

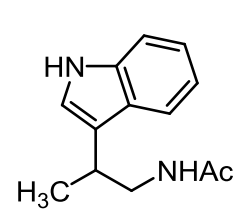

23 $44 \%$ yield

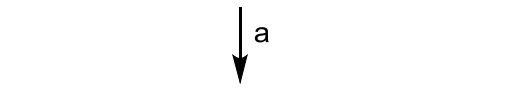

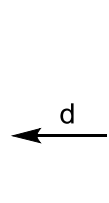

d

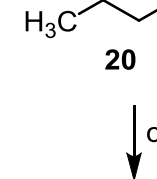<smiles>CC(CNCc1ccccc1)c1c[nH]c2ccccc12</smiles>

22

$45 \%$ yield

Reagents and Conditions: a) $10 \% \mathrm{Pd} / \mathrm{C}, \mathrm{H}_{2}, \mathrm{CH}_{3} \mathrm{OH}$, rt, $4 \mathrm{~h}$; b) $37 \%$ formaldehyde in $\mathrm{H}_{2} \mathrm{O}, \mathrm{NaBH}_{4}, \mathrm{CH}_{3} \mathrm{OH}, 0^{\circ} \mathrm{C}, 1 \mathrm{~h}$; c) benzaldehyde, $\mathrm{CH}_{3} \mathrm{OH}$, rt, $24 \mathrm{~h}$, then $\mathrm{NaBH}_{4}$; d) $\mathrm{Ac}_{2} \mathrm{O}, \mathrm{TEA}, \mathrm{CH}_{2} \mathrm{Cl}_{2}$, rt, $18 \mathrm{~h}$.

Scheme 3: Deprotection and Functionalization of PNZ-Tryptamine 9

A general method for the synthesis of $\beta$-substituted tryptamines by the addition of indoles to aziridines has been described. The PNZ protecting group functions to activate the aziridine for selective addition and is removed from the tryptamine product under mild conditions. Future 
experiments will be directed toward expansion of our $\beta$-substituted tryptamine library, and further development of ring opening reactions with underutilized PNZ-protected aziridines.

\section{Acknowledgements}

The authors are grateful to the National Institute of General Medical Sciences of the National Institutes of Health (R15GM114766) for financial support. The HRMS data was collected by using a Bruker MicrOTOF-Q II purchased with funds from the NSF (CHE1039784) and UNCW.

\section{Experimental}

General. $\quad{ }^{1} \mathrm{H}$ NMR spectra were recorded on Bruker DRX (400 MHz) or Bruker Avance $(600 \mathrm{MHz})$ spectrometer. Chemical shifts are reported in ppm from tetramethylsilane with the solvent resonance as the internal standard $\left(\mathrm{CDCl}_{3}: 7.27 \mathrm{ppm}\right)$. Data are reported as follows: chemical shift, multiplicity $(\mathrm{s}=$ singlet, $\mathrm{d}=$ doublet, $\mathrm{t}=$ triplet, $\mathrm{q}=$ quartet, $\mathrm{br}=$ broad, $\mathrm{m}=$ multiplet), coupling constants (Hz), and integration. ${ }^{13} \mathrm{C}$ NMR spectra were recorded on a Bruker DRX 400 (100 MHz) or Bruker Avance 600 (151 MHz) spectrometer with complete proton decoupling. Chemical shifts are reported in ppm from tetramethylsilane with the solvent as the internal standard $\left(\mathrm{CDCl}_{3}: 77.1 \mathrm{ppm}\right)$. High resolution mass spectrometry was acquired with a Bruker MicrOTOF-Q II at the University of North Carolina Wilmington. Infrared (IR) spectra were obtained using a Nicolet iS5 FT-IR.

Liquid chromatography was performed using forced flow (flash chromatography) on silica gel $\left(\mathrm{SiO}_{2}, 32\right.$ to $\left.63 \mu \mathrm{m}\right)$ purchased from Dynamic Absorbents Inc. Thin layer 
chromatography (TLC) was performed on EMD Chemicals $0.25 \mathrm{~mm}$ silica gel 60 plates. Visualization was achieved UV light $(254 \mathrm{~nm})$ or basic potassium permanganate in water followed by heating. High pressure liquid chromatography (HPLC) was performed on an HP instrument equipped with an autosampler and a UV detector.

All reactions were conducted in oven and flame dried glassware under an inert atmosphere of argon. All solvents were EMD Chemicals anhydrous solvents in Sure-Seal bottles sold by VWR International, unless otherwise noted. 2-Methylaziridine (90\%) was purchased from Aldrich Chemical Company. 4-Nitrobenzyl chloroformate was purchased from the Acros Chemical Company. All reagents were used as received.

\section{Representative Procedure for Synthesis of Aziridine 6.}

A $250 \mathrm{~mL}$ round bottom flask with a Teflon ${ }^{\circledR}$-coated magnetic stir bar was charged with $50 \mathrm{~mL}$ of THF and $20 \mathrm{~mL}$ of $\mathrm{H}_{2} \mathrm{O}$. Solid sodium carbonate $(6.36 \mathrm{~g}, 60 \mathrm{mmol})$ and 2methylaziridine $(1.57 \mathrm{~mL}, 20 \mathrm{mmol})$ were added to the stirred suspension at room temperature under argon. The flask was cooled to $0{ }^{\circ} \mathrm{C}$ where 4-nitrobenzyl chloroformate $(4.67 \mathrm{~g}, 21 \mathrm{mmol})$ in $10 \mathrm{~mL}$ of THF was added dropwise. The mixture was stirred at $0{ }^{\circ} \mathrm{C}$ for 1 hour and then diluted with $30 \mathrm{~mL}$ of $\mathrm{H}_{2} \mathrm{O}$ and $40 \mathrm{~mL}$ of ethyl acetate. The flask was warmed to room temperature and the organic layer was taken. The aqueous layer was extracted twice with $25 \mathrm{~mL}$ of ethyl acetate. The combined organics layer was then washed with $30 \mathrm{~mL}$ of brine and dried over $\mathrm{MgSO}_{4}$. The crude reaction was concentrated via rotary evaporation and further purified by silica gel chromatography (4:1 hexanes/acetone) to yield rac-6 (3.23 g, 62\% yield) as a white solid. An enantioenriched sample of 6 was synthesized from $(S)$-2-methylaziridine. ${ }^{50}$

4-nitrobenzyl 2-methylaziridine-1-carboxylate. ${ }^{1} \mathrm{H}$ NMR $(400 \mathrm{MHz}$, Chloroform- $d$ ) $\delta$ $8.23(\mathrm{~d}, J=8.7 \mathrm{~Hz}, 2 \mathrm{H}), 7.54(\mathrm{~d}, J=8.7 \mathrm{~Hz}, 2 \mathrm{H}), 5.27-5.18(\mathrm{~m}, 2 \mathrm{H}), 2.61-2.53(\mathrm{~m}, 1 \mathrm{H}), 2.38$ $(\mathrm{d}, J=5.9 \mathrm{~Hz}, 1 \mathrm{H}), 2.02(\mathrm{~d}, J=3.9 \mathrm{~Hz}, 1 \mathrm{H}), 1.32(\mathrm{~d}, J=5.6 \mathrm{~Hz}, 3 \mathrm{H}) .{ }^{13} \mathrm{C} \mathrm{NMR}(151 \mathrm{MHz}$, Chloroform- $d$ ) $\delta$ 163.0, 147.9, 143.3, 128.5, 124.0, 66.6, 34.3, 32.9, 17.6. HRMS: Calculated for $\mathrm{C}_{11} \mathrm{H}_{12} \mathrm{~N}_{2} \mathrm{NaO}_{4}^{+}: 259.0689\left(\mathrm{M}+\mathrm{Na}^{+}\right)$, found $259.0697\left(\mathrm{M}+\mathrm{Na}^{+}\right)$. IR (diamond ATR crystal): 1713, 1536, 2969, 2933, 3110, 3087.

\section{Representative Procedure for Synthesis of Aziridine 8.}


In a flame-dried round bottom flask equipped with a Teflon®-coated magnetic stir bar the lithium naphthalenide reagent was freshly prepared by vigorously stirring finely chopped lithium metal (1.0 equiv) and naphthalene (1.1 equiv) in dry THF (1 M) under argon for 24 hours at room temperature.

A flame-dried round bottom flask equipped with a Teflon®-coated magnetic stir bar was charged with $3.77 \mathrm{~g}(15 \mathrm{mmol})$ of 7-tosyl-7-azabicyclo[4.1.0]heptane ${ }^{11}$ and $60 \mathrm{~mL}$ of THF. The solution was cooled to $-78{ }^{\circ} \mathrm{C}$ in a dry ice and acetone bath. The lithium naphthalenide reagent was added dropwise until the dark green endpoint was observed ( $40 \mathrm{~mL}$ of stock $1 \mathrm{M}$ solution). The reaction was quenched with $20 \mathrm{~mL}$ of aqueous saturated sodium bicarbonate and slowly warmed to $0{ }^{\circ} \mathrm{C}$. Solid 4-nitrobenzyl chloroformate $(3.50 \mathrm{~g}, 16.2 \mathrm{mmol})$ was added all at once, and the suspension was stirred for a total of 2 hours at $0{ }^{\circ} \mathrm{C}$. After this time, the mixture was diluted with $20 \mathrm{~mL}$ of $\mathrm{H}_{2} \mathrm{O}$ and $30 \mathrm{~mL}$ of ethyl acetate. The flask was warmed to room temperature and the organic layer was taken. The aqueous layer was extracted twice with $20 \mathrm{~mL}$ of ethyl acetate. The combined organics layer was then washed with $30 \mathrm{~mL}$ of brine and dried over $\mathrm{MgSO}_{4}$. The crude reaction mixture was concentrated and further purified with silica gel chromatography (4:1 hexanes/ethyl acetate) to yield $2.74 \mathrm{~g}$ (66\% yield) of $\mathbf{8}$ as a white solid.

4-nitrobenzyl 7-azobicyclo[4.1.0]heptane-7-carboxylate. ${ }^{1} \mathrm{H}$ NMR $(600 \mathrm{MHz}$, Chloroform- $d$ ) $\delta 8.21(\mathrm{~d}, J=8.7 \mathrm{~Hz}, 2 \mathrm{H}), 7.52(\mathrm{~d}, J=8.7 \mathrm{~Hz}, 2 \mathrm{H}), 5.20(\mathrm{~s}, 2 \mathrm{H}), 2.72-2.67$ (m, $2 \mathrm{H}), 1.99-1.91(\mathrm{~m}, 2 \mathrm{H}), 1.85-1.78(\mathrm{~m}, 2 \mathrm{H}), 1.46-1.37(\mathrm{~m}, 2 \mathrm{H}), 1.29-1.21(\mathrm{~m}, 2 \mathrm{H}) .{ }^{13} \mathrm{C}$ NMR (151 MHz, Chloroform-d) $\delta 163.5,147.7,143.5,128.4,123.8,66.3,37.4,23.7,19.8$. HRMS: Calculated for $\mathrm{C}_{14} \mathrm{H}_{17} \mathrm{NNaO}_{2}^{+}: 299.1002\left(\mathrm{M}+\mathrm{Na}^{+}\right)$, found $299.1014\left(\mathrm{M}+\mathrm{Na}^{+}\right)$. IR (diamond ATR crystal): 1348, 1534, 1709, 2854, 2934, 3316.

\section{Enantiospecific Synthesis of $\boldsymbol{\beta}$-Substituted Tryptamine 7}

A 1 dram vial equipped with a Teflon ${ }^{\circledR}$-coated magnetic stir bar was purged with argon. The flask was charged with aziridine $6(0.0236 \mathrm{~g}, 0.1 \mathrm{mmol})$ and 1-methylindole $(0.0374 \mathrm{~mL}$, $0.3 \mathrm{mmol})$. Dry DCM $(0.5 \mathrm{~mL}, 0.20 \mathrm{M})$ was added, and the solution was cooled to $-78{ }^{\circ} \mathrm{C}$ with a dry ice/acetone bath. A $1 \mathrm{M}$ solution of $\mathrm{BF}_{3} \cdot \mathrm{OEt}_{2}$ in $\mathrm{DCM}(0.1 \mathrm{~mL}, 0.1 \mathrm{mmol})$ was then added dropwise. The reaction was stirred for a total of 1 hour at $-78^{\circ} \mathrm{C}$ and then quenched with $0.5 \mathrm{~mL}$ of aqueous saturated sodium bicarbonate. After slowly warming to room temperature, the mixture was extracted with $1 \mathrm{~mL}$ ethyl acetate three times and the combined organic layers were 
dried over $\mathrm{MgSO}_{4}$. The crude reaction mixture was then filtered and concentrated via rotary evaporation. The crude mixture was purified using silica gel chromatography (3:1 hexanes/ethyl acetate) afforded tryptamine 7 as a viscous yellow oil in $71 \%$ yield $(0.0260 \mathrm{~g})$.

4-nitrobenzyl (2-(1-methyl-1 $\boldsymbol{H}$-indol-3-yl)propyl) carbamate. ${ }^{1} \mathrm{H}$ NMR $(400 \mathrm{MHz}$, Chloroform- $d$ ) $\delta 8.19$ (d, $J=8.5 \mathrm{~Hz}, 2 \mathrm{H}), 7.65(\mathrm{~d}, J=7.9 \mathrm{~Hz}, 1 \mathrm{H}), 7.45(\mathrm{~d}, J=8.5 \mathrm{~Hz}, 2 \mathrm{H}), 7.34$ $(\mathrm{d}, J=8.1 \mathrm{~Hz}, 1 \mathrm{H}), 7.26(\mathrm{t}, J=7.2 \mathrm{~Hz}, 1 \mathrm{H}), 7.00(\mathrm{t}, J=7.5 \mathrm{~Hz}, 1 \mathrm{H}) 6.89(\mathrm{~s}, 1 \mathrm{H}), 5.19(\mathrm{~d}, J=$ 13.4 Hz, 1H), 5.16 (d, $J=13.4 \mathrm{~Hz}, 1 \mathrm{H}), 4.87$ (br s, 1H), 3.77 (s, 3H), $3.59-3.52$ (m, 1H), $3.52-$ $3.44(\mathrm{~m}, 1 \mathrm{H}), 3.35-3.26(\mathrm{~m}, 1 \mathrm{H}), 1.40(\mathrm{~d}, J=7.0 \mathrm{~Hz}, 3 \mathrm{H}) .{ }^{13} \mathrm{C} \mathrm{NMR}\left(151 \mathrm{MHz}, \mathrm{CDCl}_{3}\right) \delta$ 156.0, 147.6, 144.3, 137.3, 128.1, 127.1, 125.7, 123.8, 122.0, 119.3, 119.0, 117.0, 109.5, 65.1, 47.5, 32.8, 31.5, 18.9. HRMS: Calculated for $\mathrm{C}_{20} \mathrm{H}_{21} \mathrm{~N}_{3} \mathrm{NaO}_{4}{ }^{+}: 390.1424\left(\mathrm{M}+\mathrm{Na}^{+}\right)$, found $390.1433\left(\mathrm{M}+\mathrm{Na}^{+}\right)$. IR (diamond ATR crystal): 1514, 1716, 2875, 2929, 2961, 3411.

\section{Representative for the Synthesis of $\beta$-Substituted Tryptamines}

A flame-dried round bottom flask equipped with a Teflon®-coated magnetic stir bar was purged with argon. The flask was charged with the required aziridine $(1 \mathrm{mmol})$ and indole (3 $\mathrm{mmol})$. Dry DCM $(5 \mathrm{~mL}, 0.20 \mathrm{M})$ was added, and the solution was cooled to $-78^{\circ} \mathrm{C}$ with a dry ice/acetone bath. A $1 \mathrm{M}$ solution of $\mathrm{BF}_{3} \cdot \mathrm{OEt}_{2}$ in $\mathrm{DCM}(1 \mathrm{~mL}, 1 \mathrm{mmol})$ was then added dropwise. The reaction was stirred for a total of 2 hours at $-78^{\circ} \mathrm{C}$ and then quenched with $5 \mathrm{~mL}$ of aqueous saturated sodium bicarbonate. After slowly warming to room temperature, the mixture was extracted with $10 \mathrm{~mL}$ ethyl acetate three times and the combined organic layers were dried over $\mathrm{MgSO}_{4}$. The crude reaction mixture was then filtered and concentrated via rotary evaporation. The crude mixture was purified using silica gel chromatography yielding the respective $\beta$-substituted tryptamine.

4-nitrobenzyl (2-(1H-indol-3-yl)propyl)carbamate (9). Synthesized from $0.2362 \mathrm{~g}$ of rac-6 and $0.3514 \mathrm{~g}$ of $1 \mathrm{H}$-indole by the standard procedure. Purification by silica gel chromatography (3:2 hexanes/ethyl acetate) afforded a yellow solid in $71 \%$ yield $(0.2499 \mathrm{~g}) .{ }^{1} \mathrm{H}$ NMR (600 MHz, Chloroform- $d$ ) $\delta 8.20$ (d, $J=8.4 \mathrm{~Hz}, 2 \mathrm{H}$ ), 8.04 (br s, 1H), 7.66 (d, $J=8.0 \mathrm{~Hz}$, $1 \mathrm{H}), 7.45(\mathrm{~d}, J=8.3 \mathrm{~Hz}, 2 \mathrm{H}), 7.40(\mathrm{~d}, J=8.1 \mathrm{~Hz}, 1 \mathrm{H}), 7.23(\mathrm{t}, J=7.6 \mathrm{~Hz}, 1 \mathrm{H}), 7.13(\mathrm{t}, J=7.5$ $\mathrm{Hz}, 1 \mathrm{H}), 7.05$ (s, 1H), 5.19 (d, $J=12.0 \mathrm{~Hz}, 1 \mathrm{H}), 5.15$ (d, $J=12.0 \mathrm{~Hz}, 1 \mathrm{H}), 4.82($ br s, $1 \mathrm{H}), 3.60$ $-3.46(\mathrm{~m}, 2 \mathrm{H}), 3.36-3.26(\mathrm{~m}, 1 \mathrm{H}), 1.41(\mathrm{~d}, J=7.0 \mathrm{~Hz}, 3 \mathrm{H}) .{ }^{13} \mathrm{C} \mathrm{NMR}(151 \mathrm{MHz}$, Chloroform- $d$ ) $\delta 156.1,147.6,144.3,136.7,128.1,126.7,123.8,122.4,120.9,119.6,119.2$, 
118.6, 111.5, 65.1, 47.3, 31.6, 18.7. HRMS: Calculated for $\mathrm{C}_{19} \mathrm{H}_{19} \mathrm{~N}_{3} \mathrm{NaO}_{4}{ }^{+}$: 376.1267 $\left(\mathrm{M}+\mathrm{Na}^{+}\right)$, found $376.1275\left(\mathrm{M}+\mathrm{Na}^{+}\right)$. IR (diamond ATR crystal): 1509, 1715, 3313, 3405.

4-nitrobenzyl (2-(2-methyl-1H-indol-3-yl)propyl) carbamate (10). Synthesized from $0.2362 \mathrm{~g}$ of rac-6 and $0.3935 \mathrm{~g}$ of 2 -methylindole by the standard procedure. Purification by silica gel chromatography (1\% acetone in DCM) afforded a yellow solid in $90 \%$ yield $(0.3327 \mathrm{~g})$ ${ }^{1} \mathrm{H}$ NMR $(600 \mathrm{MHz}$, Chloroform- $d) \delta 8.18(\mathrm{~d}, J=8.6 \mathrm{~Hz}, 2 \mathrm{H}), 7.89$ (s, 1H), 7.59 (d, J = 7.9 Hz, $1 \mathrm{H}), 7.42(\mathrm{~d}, J=8.4 \mathrm{~Hz}, 2 \mathrm{H}), 7.30(\mathrm{~d}, J=8.1 \mathrm{~Hz}, 1 \mathrm{H}), 7.14(\mathrm{t}, J=7.5 \mathrm{~Hz}, 1 \mathrm{H}), 7.07$ (t, $J=7.5$ Hz, 1H), 5.15 (s, 2H), 4.77 (br s 1H), $3.74-3.67$ (m, 1H), $3.48-3.41$ (m, 1H), $3.28-3.19$ (m, 1H), $2.36(\mathrm{~s}, 3 \mathrm{H}), 1.44(\mathrm{~d}, J=7.1 \mathrm{~Hz}, 3 \mathrm{H}) .{ }^{13} \mathrm{C}$ NMR (151 MHz, Chloroform-d) $\delta 155.8,147.5$, 144.2, 135.5, 131.6, 128.0, 127.0, 123.7, 123.7, 121.1, 119.2, 118.9, 112.5, 110.6, 64.9, 46.4, 31.7, 18.3, 12.0. HRMS: Calculated for $\mathrm{C}_{20} \mathrm{H}_{21} \mathrm{~N}_{3} \mathrm{NaO}_{4}{ }^{+}: 390.1424\left(\mathrm{M}+\mathrm{Na}^{+}\right)$, found 390.1437 $\left(\mathrm{M}+\mathrm{Na}^{+}\right)$. IR (diamond ATR crystal): 1514, 1701, 2926, 2959, 3333, 3398.

4-nitrobenzyl (2-(5-methyl-1H-indol-3-yl)propyl) carbamate (11). Synthesized from $0.2362 \mathrm{~g}$ of rac-6 and $0.3935 \mathrm{~g}$ of 5 -methylindole by the standard procedure. Purification by silica gel chromatography (3:2 hexanes/ethyl acetate) afforded a yellow solid in $65 \%$ yield (0.2431 g). ${ }^{1} \mathrm{H}$ NMR (600 MHz, Chloroform- $d$ ) $\delta 8.18(\mathrm{~d}, J=8.7 \mathrm{~Hz}, 2 \mathrm{H}), 8.02$ (br s, 1H), 7.44 $(\mathrm{d}, J=2.0 \mathrm{~Hz}, 2 \mathrm{H}), 7.43(\mathrm{~s}, 1 \mathrm{H}), 7.28(\mathrm{~d}, J=8.3 \mathrm{~Hz}, 1 \mathrm{H}), 7.06(\mathrm{~d}, J=8.3 \mathrm{~Hz}, 1 \mathrm{H}), 6.99(\mathrm{~s}, 1 \mathrm{H})$, 5.17 (s, 2H), 4.85 (br s, 1H), $3.60-3.53(\mathrm{~m}, 1 \mathrm{H}), 3.53-3.46(\mathrm{~m}, 1 \mathrm{H}), 3.33-3.24(\mathrm{~m}, 1 \mathrm{H}), 2.46$ $(\mathrm{s}, 3 \mathrm{H}), 1.40(\mathrm{~d}, J=7.0 \mathrm{~Hz}, 3 \mathrm{H}) .{ }^{13} \mathrm{C}$ NMR $(151 \mathrm{MHz}$, Chloroform-d) $\delta 156.0,147.5,144.2$, 134.9, 128.7, 128.0, 126.8, 123.9, 123.7, 121.0, 118.8, 117.9, 111.0, 65.0, 47.1, 31.5, 21.6, 18.7. Calculated for $\mathrm{C}_{20} \mathrm{H}_{21} \mathrm{~N}_{3} \mathrm{NaO}_{4}{ }^{+}: 390.1424\left(\mathrm{M}+\mathrm{Na}^{+}\right.$), found $390.1422\left(\mathrm{M}+\mathrm{Na}^{+}\right.$). IR (diamond ATR crystal): 1509, 1714, 2849, 2912, 2950, 3309, 3386.

4-nitrobenzyl (2-(5-methoxy-1H-indol-3-yl)propyl) carbamate (12). Synthesized from $0.2362 \mathrm{~g}$ of rac-6 and $0.4415 \mathrm{~g}$ of 5-methoxylindole by the standard procedure. Purification by silica gel chromatography (1\% THF in DCM) afforded an orange solid in $73 \%$ yield (0.2951 g). ${ }^{1} \mathrm{H}$ NMR (600 MHz, Chloroform- $d$ ) $\delta 8.18(\mathrm{~d}, J=8.9 \mathrm{~Hz}, 2 \mathrm{H}), 8.08$ (br s, $\left.1 \mathrm{H}\right)$, $7.43(\mathrm{~d}, J=8.6 \mathrm{~Hz}, 2 \mathrm{H}), 7.28(\mathrm{~d}, J=8.7 \mathrm{~Hz}, 1 \mathrm{H}), 7.10(\mathrm{~d}, J=2.5 \mathrm{~Hz}, 1 \mathrm{H}), 7.01(\mathrm{~d}, J=2.5 \mathrm{~Hz}$, $1 \mathrm{H}), 6.89(\mathrm{dd}, J=8.8,2.5 \mathrm{~Hz}, 1 \mathrm{H}), 5.18(\mathrm{~s}, 2 \mathrm{H}), 4.90$ (br s, 1H), 3.86 (s, 3H), $3.58-3.45$ (m, $2 \mathrm{H}), 3.33-3.21(\mathrm{~m}, 1 \mathrm{H}), 1.39(\mathrm{~d}, J=7.0 \mathrm{~Hz}, 3 \mathrm{H}) .{ }^{13} \mathrm{C}$ NMR (151 MHz, Chloroform- $\left.d\right) \delta 156.1$, 154.0, 147.6, 144.3, 131.8, 128.1, 127.1, 123.8, 121.6, 118.3, 112.4, 112.2, 101.2, 65.1, 56.1, 
47.3, 31.5, 18.6. HRMS: Calculated for $\mathrm{C}_{20} \mathrm{H}_{21} \mathrm{~N}_{3} \mathrm{NaO}_{5}{ }^{+}: 406.1373\left(\mathrm{M}+\mathrm{Na}^{+}\right)$, found 406.1386 $\left(\mathrm{M}+\mathrm{Na}^{+}\right)$. IR (diamond ATR crystal): 1514, 1712, 2868, 2911, 2952, 3323, 3396.

4-nitrobenzyl (2-(5-chloro-1H-indol-3-yl)propyl) carbamate (13). Synthesized from $0.2362 \mathrm{~g}$ of rac-6 and $0.4548 \mathrm{~g}$ of 5 -chloroindole by the standard procedure. Purification by silica gel chromatography (3:2 hexanes/ ethyl acetate) afforded a yellow solid in 65\% yield $(0.2551 \mathrm{~g}) .{ }^{1} \mathrm{H}$ NMR $(600 \mathrm{MHz}$, Chloroform- $d$ ) $\delta 8.20(\mathrm{br} \mathrm{s}, 1 \mathrm{H}), 8.18(\mathrm{~d}, J=8.3 \mathrm{~Hz}, 2 \mathrm{H}), 7.61$ (s, 1H), $7.44(\mathrm{~d}, J=8.3 \mathrm{~Hz}, 2 \mathrm{H}), 7.30(\mathrm{~d}, J=8.6 \mathrm{~Hz}, 1 \mathrm{H}), 7.16(\mathrm{~d}, J=8.6,1 \mathrm{H}), 7.06(\mathrm{~s}, 1 \mathrm{H}), 5.17$ (s, 2H), 4.86 (br s, 1H), $3.59-3.48(\mathrm{~m}, 1 \mathrm{H}), 3.48-3.38(\mathrm{~m}, 1 \mathrm{H}), 3.29-3.21(\mathrm{~m}, 1 \mathrm{H}), 1.38(\mathrm{~d}, J$ $=7.0 \mathrm{~Hz}, 3 \mathrm{H}) .{ }^{13} \mathrm{C}$ NMR $(151 \mathrm{MHz}$, Chloroform- $d$ ) $\delta$ 156.0, 147.5, 144.1, 134.8, 128.0, 127.8, 125.2, 123.7, 122.6, 122.1, 118.6, 118.4, 112.4, 65.1, 47.4, 31.4, 18. 6. HRMS: Calculated for $\mathrm{C}_{19} \mathrm{H}_{18} \mathrm{ClN}_{3} \mathrm{NaO}_{4}{ }^{+}: 410.0878\left(\mathrm{M}+\mathrm{Na}^{+}\right)$, found $410.0886\left(\mathrm{M}+\mathrm{Na}^{+}\right)$. IR (diamond ATR crystal): 1510, 1704, 2913, 3287, 3406.

4-nitrobenzyl (2-(6-fluoro-1H-indol-3-yl)propyl) carbamate (14). Synthesized from $0.2362 \mathrm{~g}$ of rac-6 and $0.4053 \mathrm{~g}$ of 6 -fluoroindole by the standard procedure. Purification by silica gel chromatography (3:2 hexanes/ethyl acetate) to afforded a yellow solid in $57 \%$ yield $(0.2107 \mathrm{~g}) .{ }^{1} \mathrm{H}$ NMR $(600 \mathrm{MHz}$, Chloroform- $d) \delta 8.20(\mathrm{~d}, J=8.4 \mathrm{~Hz}, 2 \mathrm{H}), 8.02(\mathrm{br} \mathrm{s}, 1 \mathrm{H}), 7.56$ (dd, $J=8.8,5.3 \mathrm{~Hz}, 1 \mathrm{H}), 7.46(\mathrm{~d}, J=8.4 \mathrm{~Hz}, 2 \mathrm{H}), 7.07$ (d, $J=9.6,1 \mathrm{H}), 7.01(\mathrm{~s}, 1 \mathrm{H}), 6.89$ (t, $J=$ $9.1 \mathrm{~Hz}, 1 \mathrm{H}), 5.17$ (s, 2H), $4.83(\mathrm{br} \mathrm{s}, 1 \mathrm{H}), 3.50$ (t, $J=6.4 \mathrm{~Hz}, 2 \mathrm{H}), 3.33-3.23(\mathrm{~m}, 1 \mathrm{H}), 1.39$ (d, $J$ $=7.0 \mathrm{~Hz}, 3 \mathrm{H}) .{ }^{13} \mathrm{C}$ NMR $(151 \mathrm{MHz}$, Chloroform- $d) \delta 160.0(\mathrm{~d}, J=237.9 \mathrm{~Hz}), 156.1,147.5$, 144.2, $136.5(\mathrm{~d}, J=12.4 \mathrm{~Hz}), 128.0,123.7,123.3,121.1(\mathrm{~d}, J=3.5 \mathrm{~Hz}), 119.8(\mathrm{~d}, J=10.1 \mathrm{~Hz})$, 118.6, $108.2(\mathrm{~d}, J=24.5 \mathrm{~Hz}), 97.7(\mathrm{~d}, J=25.8 \mathrm{~Hz}), 65.1,47.3,31.5$, 18.5. HRMS: Calculated for $\mathrm{C}_{19} \mathrm{H}_{18} \mathrm{FN}_{3} \mathrm{NaO}_{4}{ }^{+}$: $394.1173\left(\mathrm{M}+\mathrm{Na}^{+}\right)$, found $394.1183\left(\mathrm{M}+\mathrm{Na}^{+}\right)$. IR (diamond ATR crystal): 1708, 2954, 2914, 3284, 3397.

4-nitrobenzyl (2-(1H-indol-3-yl)cyclohexyl)carbamate (15). Synthesized from 0.2763 $\mathrm{g}$ of $\mathbf{8}$ and $0.3514 \mathrm{~g}$ of $1 \mathrm{H}$-indole by the standard procedure. Purification by silica gel chromatography (2:1 hexanes/ethyl acetate) afforded a yellow solid in 73\% yield $(0.2903 \mathrm{~g}){ }^{1} \mathrm{H}$ NMR (400 MHz, Chloroform- $d$ ) $\delta 8.18$ (br s, 1H), 8.05 (d, $J=8.0 \mathrm{~Hz}, 2 \mathrm{H}), 7.64(\mathrm{~d}, J=7.6 \mathrm{~Hz}$, $1 \mathrm{H}), 7.39$ (d, $J=7.4 \mathrm{~Hz}, 1 \mathrm{H}), 7.22(\mathrm{t}, J=7.2 \mathrm{~Hz}, 1 \mathrm{H}), 7.13(\mathrm{t}, J=7.1 \mathrm{~Hz}, 2 \mathrm{H}), 7.09(\mathrm{~d}, J=7.1$ Hz, 1H), $7.00(\mathrm{~s}, 1 \mathrm{H}), 5.03(\mathrm{~d}, J=13.6 \mathrm{~Hz}, 1 \mathrm{H}), 4.90(\mathrm{~d}, J=13.6 \mathrm{~Hz}, 1 \mathrm{H}), 4.77$ (br s, 1H), $3.92-$ $3.77(\mathrm{~m}, 1 \mathrm{H}), 2.85-2.73(\mathrm{~m}, 1 \mathrm{H}), 2.32-2.23(\mathrm{~m}, 1 \mathrm{H}), 2.16-2.05(\mathrm{~m}, 1 \mathrm{H}), 1.94-1.77(\mathrm{~m}$, 2H), $1.65-1.31(\mathrm{~m}, 4 \mathrm{H}) .{ }^{13} \mathrm{C}$ NMR (151 MHz, Chloroform- $d$ ) $\delta 155.4,147.3,144.5,136.2$, 
127.4, 127.2, 123.6, 122.0, 120.8, 119.4, 118.7, 118.3, 111.4, 64.6, 55.2, 41.5, 34.7, 34.6, 26.3, 25.5. HRMS: Calculated for $\mathrm{C}_{22} \mathrm{H}_{23} \mathrm{~N}_{3} \mathrm{NaO}_{4}{ }^{+}: 416.1581\left(\mathrm{M}+\mathrm{Na}^{+}\right)$, found $416.1586\left(\mathrm{M}+\mathrm{Na}^{+}\right)$. IR (diamond ATR crystal): 1512, 1712, 2855, 2928, 3311, 3401.

4-nitrobenzyl (2-(2-methyl-1H -indol-3-yl)cyclohexyl) carbamate (16). Synthesized from $0.2763 \mathrm{~g}$ of $\mathbf{8}$ and $0.3935 \mathrm{~g}$ of 2-methylindole by the standard procedure. Purification by silica gel chromatography (1\% acetone in DCM) afforded a yellow solid in $78 \%$ yield $(0.3112$ g). ${ }^{1} \mathrm{H}$ NMR (600 MHz, DMSO- $\left.d_{6}\right) \delta 10.65(\mathrm{~s}, 1 \mathrm{H}), 8.07(\mathrm{~d}, J=8.2 \mathrm{~Hz}, 2 \mathrm{H}), 7.54(\mathrm{~d}, J=7.9 \mathrm{~Hz}$, 1H), $7.21(\mathrm{~d}, J=8.0 \mathrm{~Hz}, 2 \mathrm{H}), 7.18-7.01(\mathrm{~m}, 2 \mathrm{H}), 7.01-6.79(\mathrm{~m}, 2 \mathrm{H}), 4.99(\mathrm{~d}, J=14.5 \mathrm{~Hz}$, $1 \mathrm{H}), 4.87(\mathrm{~d}, J=14.5 \mathrm{~Hz}, 1 \mathrm{H}), 3.90(\mathrm{~m}, 1 \mathrm{H}), 2.74(\mathrm{~m}, 1 \mathrm{H}), 2.33(\mathrm{~s}, 3 \mathrm{H}), 2.05-1.65(\mathrm{~m}, 4 \mathrm{H})$, $1.54-1.20(\mathrm{~m}, 4 \mathrm{H}) .{ }^{13} \mathrm{C}$ NMR $\left(151 \mathrm{MHz}\right.$, DMSO- $\left.d_{6}\right) \delta 154.7,146.6,145.7,135.2,131.7,127.2$, 126.9, 123.3, , 119.3, 118.8, 117.6, 112.0, 110.2, 63.1, 52.8, 40.5, 34.1, 32.5, 26.1, 25.3. HRMS: Calculated for $\mathrm{C}_{23} \mathrm{H}_{25} \mathrm{~N}_{3} \mathrm{NaO}_{4}{ }^{+}: 430.1737\left(\mathrm{M}+\mathrm{Na}^{+}\right)$, found $430.1736\left(\mathrm{M}+\mathrm{Na}^{+}\right)$. IR (diamond ATR crystal): 1508, 1708, 2854, 2912, 3339, 3399.

4-nitrobenzyl (2-(5-methyl-1H-indol-3-yl) cyclohexyl) carbamate (17). Synthesized from $0.2763 \mathrm{~g}$ of $\mathbf{8}$ and $0.3935 \mathrm{~g}$ of 5 -methylindole by the standard procedure. Purification by silica gel chromatography (3:2 hexanes/ethyl acetate) afforded a yellow solid in 59\% yield $(0.2422 \mathrm{~g}) .{ }^{1} \mathrm{H}$ NMR $(600 \mathrm{MHz}$, Chloroform- $d$ ) $\delta 8.05(\mathrm{~d}, J=8.1 \mathrm{~Hz}, 2 \mathrm{H}), 8.02(\mathrm{br} \mathrm{s}, 1 \mathrm{H}), 7.40$ (s, 1H), 7.27 (d, $J=8.1 \mathrm{~Hz}, 1 \mathrm{H}), 7.11(\mathrm{~d}, J=8.3 \mathrm{~Hz}, 2 \mathrm{H}), 7.04(\mathrm{~d}, J=8.2 \mathrm{~Hz}, 1 \mathrm{H}), 6.97$ (s, 1H), $5.02(\mathrm{~d}, J=13.7 \mathrm{~Hz}, 1 \mathrm{H}), 4.91(\mathrm{~d}, J=13.7 \mathrm{~Hz}, 1 \mathrm{H}), 4.74(\mathrm{br} \mathrm{s}, 1 \mathrm{H}), 3.88-3.76(\mathrm{~m}, 1 \mathrm{H}), 2.82-$ $2.68(\mathrm{~m}, 1 \mathrm{H}), 2.45(\mathrm{~s}, 3 \mathrm{H}), 2.32-2.24(\mathrm{~m}, 1 \mathrm{H}), 2.14-2.06(\mathrm{~m}, 1 \mathrm{H}), 1.92-1.77(\mathrm{~m}, 2 \mathrm{H}), 1.64-$ $1.30(\mathrm{~m}, 4 \mathrm{H}) .{ }^{13} \mathrm{C}$ NMR (151 MHz, Chloroform- $d$ ) $\delta$ 155.4, 147.3, 144.5, 134.6, 128.6, 127.4, 123.6, 121.0, 118.3, 117.8, 111.1, 64.6, 55.1, 41.5, 34.8, 34.6, 26.3, 25.5, 21.7. Calculated for $\mathrm{C}_{23} \mathrm{H}_{25} \mathrm{~N}_{3} \mathrm{NaO}_{4}{ }^{+}: 430.1737\left(\mathrm{M}+\mathrm{Na}^{+}\right)$, found $430.1735\left(\mathrm{M}+\mathrm{Na}^{+}\right)$. IR (diamond ATR crystal): 1520, 1700, 2865, 2917, 3338, 3390, 3407.

4-nitrobenzyl (2-(5-methoxy-1H-indol-3-yl) cyclohexyl) carbamate (18). Synthesized from $0.2763 \mathrm{~g}$ of $\mathbf{8}$ and $0.4415 \mathrm{~g}$ of 5 -methoxylindole by the standard procedure. Purification by silica gel chromatography ( $2 \%$ acetone in DCM) afforded a yellow solid in 63\% yield $(0.2626$ g). ${ }^{1} \mathrm{H}$ NMR (400 MHz, Chloroform- $d$ ) $\delta 8.08(\mathrm{~d}, J=8.7 \mathrm{~Hz}, 2 \mathrm{H}), 7.87$ (br s, $\left.1 \mathrm{H}\right), 7.28$ (d, $J=$ $8.7 \mathrm{~Hz}, 1 \mathrm{H}), 7.16(\mathrm{~d}, J=8.7 \mathrm{~Hz}, 2 \mathrm{H}), 7.03(\mathrm{~s}, 2 \mathrm{H}), 6.88(\mathrm{dd}, J=8.8,2.4 \mathrm{~Hz}, 1 \mathrm{H}), 5.03(\mathrm{~d}, J=$ $13.8 \mathrm{~Hz}, 1 \mathrm{H}), 4.93(\mathrm{~d}, J=13.8 \mathrm{~Hz}, 1 \mathrm{H}), 4.67(\mathrm{br} \mathrm{s}, 1 \mathrm{H}), 3.86(\mathrm{~s}, 3 \mathrm{H}), 3.87-3.73(\mathrm{~m}, 1 \mathrm{H}), 2.78-$ $2.65(\mathrm{~m}, 1 \mathrm{H}), 2.31-2.21(\mathrm{~m}, 1 \mathrm{H}), 2.16-2.06(\mathrm{~m}, 1 \mathrm{H}), 1.92-1.76(\mathrm{~m}, 2 \mathrm{H}), 1.61-1.29(\mathrm{~m}$, 
4H). ${ }^{13} \mathrm{C}$ NMR (151 MHz, Chloroform-d) $\delta$ 155.4, 154.0, 147.3, 144.5, 131.4, 127.7, 127.5, 123.7, 121.7, 118.0, 112.0, 111.9, 100.9, 64.6, 56.1, 55.2, 41.5, 34.7, 34.6, 26.3, 25.5. HRMS: Calculated for $\mathrm{C}_{23} \mathrm{H}_{25} \mathrm{~N}_{3} \mathrm{NaO}_{5}{ }^{+}: 446.1686\left(\mathrm{M}+\mathrm{Na}^{+}\right)$, found $446.1688\left(\mathrm{M}+\mathrm{Na}^{+}\right)$. IR (diamond ATR crystal): 1515, 1692, 2849, 2913, 2935, 3322, 3409.

4-nitrobenzyl (2-(1-methyl-1H-indol-3-yl) cyclohexyl) carbamate (19). Synthesized from $0.2763 \mathrm{~g}$ of $\mathbf{8}$ and $0.375 \mathrm{~mL}$ of 1 -methylindole by the standard procedure. Purification by silica gel chromatography (3:2 hexanes/ethyl acetate) afforded a yellow solid in $63 \%$ yield $(0.2607 \mathrm{~g}) .{ }^{1} \mathrm{H}$ NMR (600 MHz, Chloroform- $\left.d\right) \delta 8.07(\mathrm{~d}, J=8.3 \mathrm{~Hz}, 2 \mathrm{H}), 7.63$ (d, $J=7.8 \mathrm{~Hz}$, $1 \mathrm{H}), 7.33(\mathrm{~d}, J=8.2 \mathrm{~Hz}, 1 \mathrm{H}), 7.25(\mathrm{~d}, J=7.8 \mathrm{~Hz}, 1 \mathrm{H}), 7.15(\mathrm{~d}, J=8.3 \mathrm{~Hz}, 2 \mathrm{H}), 7.12(\mathrm{t}, J=7.5$ Hz, 1H), 6.90 (s, 1H), 5.05 (d, J=13.9 Hz, 1H), 4.94 (d, J=13.9 Hz, 1H), 4.74 (br s, 1H), $3.86-$ $3.76(\mathrm{~m}, 1 \mathrm{H}), 3.71(\mathrm{~s}, 3 \mathrm{H}), 2.84-2.72(\mathrm{~m}, 1 \mathrm{H}), 2.35-2.26(\mathrm{~m}, 1 \mathrm{H}), 2.16-2.05(\mathrm{~m}, 1 \mathrm{H}), 1.92-$ $1.78(\mathrm{~m}, 2 \mathrm{H}), 1.65-1.28(\mathrm{~m}, 4 \mathrm{H}) .{ }^{13} \mathrm{C} \mathrm{NMR}(151 \mathrm{MHz}$, Chloroform- $d) \delta 155.3,147.3,144.6$, 137.0, 127.6, 127.5, 125.6, 123.6, 121.6, 118.9, 118.8, 116.9, 109.5, 64.6, 55.2, 41.4, 35.1, 34.6, 32.8, 26.3, 25.5. HRMS: Calculated for $\mathrm{C}_{23} \mathrm{H}_{25} \mathrm{~N}_{3} \mathrm{NaO}_{4}{ }^{+}: 430.1737\left(\mathrm{M}+\mathrm{Na}^{+}\right)$, found 430.1737 $\left(\mathrm{M}+\mathrm{Na}^{+}\right)$. IR (diamond ATR crystal): 1521, 1542, 1692, 2848, 2915, 3328.

\section{Representative Procedure for the Tryptamine Functionalization}

An oven-dried 1-dram vial equipped with a Teflon®-coated magnetic stir bar was purged with argon. The vial was charged with $0.0706 \mathrm{~g}(0.2 \mathrm{mmol})$ of tryptamine 9 and $0.0400 \mathrm{~g}(0.02$ mmol) of $10 \%$ palladium on carbon (activated, wet). Dry methanol (1.0 mL) was added under an argon atmosphere. Hydrogen gas was bubbled into solution for 5 minutes, then the hydrogen atmosphere was maintained under balloon pressure. The reaction was stirred for 4 hours after which no starting material remained. The solution was filtered through a Celite $\bigcirc$ plug using excess methanol, and the crude filtrate was concentrated via rotary evaporation. Unpurified tryptamine $\mathbf{2 0}$ was used without purification for subsequent reactions.

2-(1H-indol-3-yl)-N,N-dimethylpropan-1-amine (21). Synthesized from tryptamine 20 $(0.33 \mathrm{mmol})$ by a published procedure. ${ }^{47}$ Purification by silica gel chromatography $(10 \%$ methanol and $1 \% \mathrm{NH}_{4} \mathrm{OH}$ in DCM) afforded a white solid in $53 \%$ yield $(0.0359 \mathrm{~g}) .{ }^{1} \mathrm{H}$ NMR $(400 \mathrm{MHz}$, Chloroform- $d$ ) $\delta 8.03$ (br s, 1H), 7.66 (d, $J=7.9 \mathrm{~Hz}, 1 \mathrm{H}), 7.35$ (d, $J=8.1,1 \mathrm{H}), 7.22$ $-7.16(\mathrm{~m}, 1 \mathrm{H}), 7.15-7.09(\mathrm{~m}, 1 \mathrm{H}), 7.00(\mathrm{~d}, J=2.4 \mathrm{~Hz}, 1 \mathrm{H}), 3.33-3.20(\mathrm{~m}, 1 \mathrm{H}), 2.61(\mathrm{dd}, J=$ 
12.0, $5.7 \mathrm{~Hz}, 1 \mathrm{H}), 2.49(\mathrm{dd}, J=12.0,9.2 \mathrm{~Hz}, 1 \mathrm{H}), 2.30(\mathrm{~s}, 6 \mathrm{H}), 1.41(\mathrm{~d}, J=6.8 \mathrm{~Hz}, 3 \mathrm{H}) .{ }^{13} \mathrm{C}$ NMR (151 MHz, $\left.\mathrm{CDCl}_{3}\right) \delta 136.6,126.9,122.0,121.0,120.3,119.3,119.2,111.4,67.1,46.1$, 29.3, 19.7.

N-benzyl-2-(1H-indol-3-yl)propan-1-amine (22). Synthesized from tryptamine $20(0.2$ $\mathrm{mmol}$ ) by a published procedure. ${ }^{48}$ Purification by silica gel chromatography (5-7.5\% methanol in DCM) afforded a yellow oil in $45 \%$ yield $(0.0238 \mathrm{~g}) .{ }^{1} \mathrm{H}$ NMR $(400 \mathrm{MHz}$, Chloroform- $d$ ) $\delta$ 8.17 (br s, 1H), 7.68 (d, $J=7.9 \mathrm{~Hz}, 1 \mathrm{H}), 7.38$ (d, $J=8.1 \mathrm{~Hz}, 1 \mathrm{H}), 7.35-7.19$ (m, 6H), 7.13 (t, $J$ $=8.0 \mathrm{~Hz}, 1 \mathrm{H}), 7.00(\mathrm{~s}, 1 \mathrm{H}), 3.86(\mathrm{~d}, J=13.4,1 \mathrm{H}), 3.81(\mathrm{~d}, J=13.4,1 \mathrm{H}), 3.42-3.30(\mathrm{~m}, 1 \mathrm{H})$, $3.04(\mathrm{dd}, J=11.4,7.9 \mathrm{~Hz}, 1 \mathrm{H}), 2.91(\mathrm{dd}, J=11.4,6.1 \mathrm{~Hz}, 1 \mathrm{H}), 2.17(\mathrm{br} \mathrm{s}, 1 \mathrm{H}), 1.42(\mathrm{~d}, J=6.9$ $\mathrm{Hz}, 3 \mathrm{H}) .{ }^{13} \mathrm{C}$ NMR $\left(151 \mathrm{MHz}, \mathrm{CDCl}_{3}\right) \delta 140.2,136.7,128.5,128.2,127.0,126.7,122.1,120.9$, 119.7, 119.5, 119.3, 111.4, 55.5, 53.8, 31.5, 19.8 .

N-(2-(1H-indol-3-yl)propyl)acetamide (23). Synthesized from tryptamine $20(0.2$ mmol) by a published procedure. ${ }^{49}$ Purification by silica gel chromatography (2:1 ethyl acetate/ hexanes) afforded a white solid in $44 \%$ yield $(0.0191 \mathrm{~g}) .{ }^{1} \mathrm{H}$ NMR (400 MHz, Chloroform- $d$ ) $\delta$ 8.25 (br s, 1H), 7.67 (d, $J=7.9 \mathrm{~Hz}, 1 \mathrm{H}), 7.40$ (d, $J=8.1 \mathrm{~Hz}, 1 \mathrm{H}), 7.22$ (t, $J=7.5,1 \mathrm{H}), 7.14$ (t, $J$ $=7.5,1 \mathrm{H}), 7.05(\mathrm{~d}, J=2.4 \mathrm{~Hz}, 1 \mathrm{H}), 5.46(\mathrm{br} \mathrm{s}, 1 \mathrm{H}), 3.73-3.64(\mathrm{~m}, 1 \mathrm{H}), 3.45$ (ddd, $J=13.2$, 8.2, $5.1 \mathrm{~Hz}, 1 \mathrm{H}), 3.35-3.24(\mathrm{~m}, 1 \mathrm{H}), 1.89(\mathrm{~s}, 3 \mathrm{H}), 1.38(\mathrm{~d}, J=7.0 \mathrm{~Hz}, 3 \mathrm{H}) .{ }^{13} \mathrm{C}$ NMR $(151$ $\left.\mathrm{MHz}, \mathrm{CDCl}_{3}\right) \delta 170.3,136.7,126.8,122.4,120.9,119.6,119.2,118.9,111.5,45.8,31.3,23.5$, 19.0 .

\section{$\underline{\text { References }}$}

(1) Chiral Amine Synthesis; Nugent, T. C., Ed.; Wiley-VCH Verlag GmbH \& Co. KGaA: Weinheim, 2010.

(2) Tanner, D. Angew Chem., Int. Ed. Engl. 1994, 33, 599-619.

(3) McCoull, W.; Davis, F. A. Synthesis 2000, 1347-1365.

(4) Dahanukar, V. H.; Zavialov, I. A. Curr. Opin. Drug Dis. Dev. 2002, 5, 918-927.

(5) $\mathrm{Hu}, \mathrm{X}$. E. Tetrahedron 2004, 60, 2701-2743.

(6) Krake, S. H.; Bergmeier, S. C. Tetrahedron 2010, 66, 7337-7360.

(7) Lu, P. F. Tetrahedron 2010, 66, 2549-2560.

(8) Callebaut, G.; Meiresonne, T.; De Kimpe, N.; Mangelinckx, S. Chem. Rev. 2014, 114, 7954-

(9) Huang, C. Y.; Doyle, A. G. Chem. Rev. 2014, 114, 8153-8198.

(10) Sweeney, J. B. Chem. Soc. Rev. 2002, 31, 247-258.

(11) Ando, T.; Kano, D.; Minakata, S.; Ryu, I.; Komatsu, M. Tetrahedron 1998, 54, 13485-13494.

(12) Jeong, J. U.; Tao, B.; Sagasser, I.; Henniges, H.; Sharpless, K. B. J. Am. Chem. Soc. 1998, 120, 6844-6845. 
(13) Müller, P.; Fruit, C. Chem. Rev. 2003, 103, 2905-2919.

(14) Maligres, P. E.; See, M. M.; Askin, D.; Reider, P. J. Tetrahedron Lett. 1997, 38, 5253-5256.

(15) Dauban, P.; Dodd, R. H. J. Org. Chem. 1999, 64, 5304-5307.

(16) Gontcharov, A. V.; Liu, H.; Sharpless, K. B. Org. Lett. 1999, 1, 783-786.

(17) Bornholdt, J.; Felding, J.; Clausen, R. P.; Kristensen, J. L. Chem. Eur. J. 2010, 16, 12474where

$\mathrm{R} 12471$ is typically a protected ester 12480.

(18) Tomasini, C.; Vecchione, A. Org. Lett. 1999, 1, 2153-2156.

(19) Cardillo, G.; Gentilucci, L.; Gianotti, M.; Tolomelli, A. Synlett 2000, 1309-1311.

(20) Lucarini, S.; Tomasini, C. J. Org. Chem. 2001, 66, 727-732.

(21) Tirotta, I.; Fifer, N. L.; Eakins, J.; Hutton, C. A. Tetrahedron Lett. 2013, 54, 618-620.

(22) Mente, P. G.; Heine, H. W. J. Org. Chem. 1971, 36, 3076-3078.

(23) Baldwin, J. E.; Adlington, R. M.; Robinson, N. G. J. Chem. Soc., Chem. Commun. 1987, 153-

(24) Mauger, A. B.; Burke, P. J.; Somani, H. H.; Friedlos, F.; Knox, R. J. J. Med. Chem. 1994, 37, $3452-3458$.

(25) McKeever, B.; Pattenden, G. Tetrahedron 2003, 59, 2701-2712.

(26) Liu, H. Q.; Pattabiraman, V. R.; Vederas, J. C. Org. Lett. 2007, 9, 4211-4214.

(27) Liu, W.; Chan, A. S. H.; Liu, H. Q.; Cochrane, S. A.; Vederas, J. C. J. Am. Chem. Soc. 2011, 133, $14216-14219$.

(28) O'Brien, K.; Kelleher, F. Tetrahedron Lett. 2013, 54, 6627-6630.

(29) O'Brien, K.; Proinsias, K. O.; Kelleher, F. Tetrahedron Lett. 2013, 54, 2395-2397.

(30) Bleriot, Y.; Tran, A. T.; Prencipe, G.; Jagadeesh, Y.; Auberger, N.; Zhu, S.; Gauthier, C.; Zhang, Y. M.; Desire, J.; Adachi, I.; Kato, A.; Sollogoub, M. Org. Lett. 2014, 16, 5516-5519.

(31) O'Brien, K.; Proinsias, K. O.; Kelleher, F. Tetrahedron 2014, 70, 5082-5092.

(32) Martin, A.; Casto, K.; Morris, W.; Morgan, J. B. Org. Lett. 2011, 13, 5444-5447.

(33) Cockrell, J.; Wilhelmsen, C.; Rubin, H.; Martin, A.; Morgan, J. B. Angew. Chem., Int. Ed. 2012, $51,9842-9845$.

(34) Kochanowska-Karamyan, A. J.; Hamann, M. T. Chem. Rev. 2010, 110, 4489-4497.

(35) Greene, S. L. In Novel Psychoactive Substances: Classification, Pharmacology, and Toxicology; Academic Press: 2013, p 363-381.

(36) Pfeil, E.; Harder, U. Angew. Chem., Int. Ed. 1967, 6, 178.

(37) Sato, K.; Kozikowski, A. P. Tetrahedron Lett. 1989, 30, 4073-4076.

(38) Shima, I.; Shimazaki, N.; Imai, K.; Hemmi, K.; Hashimoto, M. Chem. Pharm. Bull. 1990, 38, 564-566.

(39) Bennani, Y. L.; Zhu, G. D.; Freeman, J. C. Synlett 1998, 754-756.

(40) Nishikawa, T.; Ishikawa, M.; Wada, K.; Isobe, M. Synlett 2001, 945-947.

(41) Nishikawa, T.; Kajii, S.; Wada, K.; Ishikawa, M.; Isobe, M. Synthesis 2002, 1658-1662.

(42) Harada, H.; Fujii, A.; Odai, O.; Kato, S. Org. Process Res. Dev. 2004, 8, 238-245.

(43) Farr, R. N.; Alabaster, R. J.; Chung, J. Y. L.; Craig, B.; Edwards, J. S.; Gibson, A. W.; Ho, G. J.; Humphrey, G. R.; Johnson, S. A.; Grabowski, E. J. J. Tetrahedron: Asymmetry 2003, 14, 3503-3515.

(44) Stankovic, S.; D'hooghe, M.; Catak, S.; Eum, H.; Waroquier, M.; Van Speybroeck, V.; De Kimpe, N.; Ha, H. J. Chem. Soc. Rev. 2012, 41, 643-665.

(45) Ghorai, M. K.; Tiwari, D. P.; Jain, N. J. Org. Chem. 2013, 78, 7121-7130.

(46) The absolute stereochemistry of 7 was not rigorously determined in this study. Inversion of stereochemistry is inferred from previous work with Nosyl-protected aziridines (see ref. 43).

(47) Bosch, J.; Roca, T.; Armengol, M.; Fernandez-Forner, D. Tetrahedron 2001, 57, 1041-1048.

(48) Martin, D. B. C.; Vanderwal, C. D. J. Am. Chem. Soc. 2009, 131, 3472-3473.

(49) Schuck, D. C.; Jordao, A. K.; Nakabashi, M.; Cunha, A. C.; Ferreira, V. F.; Garcia, C. R. S. Eur. J. Med. Chem. 2014, 78, 375-382.

(50) Veitia, M. S. I.; Brun, P. L.; Jorda, P.; Falguieres, A.; Ferroud, C. Tetrahedron: Asymmetry 2009, 20, 2077-2089. 
